\section{Coastal Geological OCEANOGRAPHERS PROVIDE THE FOURTH DIMENSION}

$\mathrm{T}$ HE COASTAL OCEAN, defined here as waters covering the continental margin, has become an area of intense study. A driving impetus always has been to understand the complex oceanographic transitions between land and deep sea. However, recently this has been joined with a host of other more applied stimuli including: pollution concerns, military needs, commercial endeavors, and climatic relevance. Clearly the spectrum of coastal research requires studies of waves and currents, chemical composition and productivity of seawater. These imperatives explain the need for physical, chemical. and biological oceanographers, but why involve geological oceanographers?

As the trend toward interdisciplinary studies blurs boundaries, it is becoming more difficult to assign particular research to an individual discipline. Shoreline morphology was once a topic left to geologists, but in the past decade physical types have become intrigued by the interactions between flow and bed shapes on the beach and shoreface. In the past. only geologists could get excited about particle-size distributions; now chemists realize the relationships between size and the fate of particle-reactive chemical species. Sediment transport was once the domain of geologists, but now larval dispersal and benthic recruitment are closely linked to this field of study. So is there anything left that is uniquely geological? Yes.

Many oceanographers measure a property in the water column or seabed and construct a one-dimensional profile. Sometimes a transect of profiles or a series of transects create two- or three-dimensional descriptions of a variable, which can be used to interpret processes. The more motivated studies will include time-series observations, to determine how the variable changes over a tidal cycle, a storm, or a season. We applaud the monumental effort to continue Alistair Hardy's measurements over time scales of decades. However, time-series observations are difficult, expensive, and limited. Wouldn't it be nice to put our observations more easily into a temporal perspective-to have a natural record of coastal oceanic processes that spanned centuries and millennia. This is possible through the study of sedimentary strata.

The strata preserved within the seabed record evidence of past oceanic processes. For continental margins, high accumulation rates provide the added benefit of a highresolution record of processes. The keys to employing sedimentary strata effectively are two-fold: 1) documenting the record; 2) reading the record. The former involves direct (e.g., coring, drilling) and indirect (e.g., seismic profiling) investigation of the seabed, to identify as well as possible the clues preserved. The latter requires insights (e.g., through field and lab studies) regarding how to interpret the clues, and how to extrapolate (e.g., through modeling) to conditions impossible to observe. The potential is to add a fourth dimension to studies of the coastal ocean. and this is the unique contribution that geological oceanographers provide.

- Chuck Nittrouer and Joe Kravitz

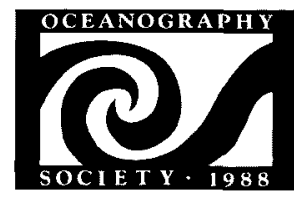

THE OCEANOGRAPHY SOCIETY

4052 Timber Ridge Drive Virginia Beach, VA 23455 USA (804) 464-0131; fax: (804) 464-1759

OFFICERS

Margaret Leinen. President Robert A. Duce. President-Elect

Melbourne G. Briscoe, Secretary David Evans, Treasurer

Arnold L. Gordon, Past-President

$$
\begin{gathered}
\text { COUNSELORS } \\
\text { Richard T. Barber } \\
\text { Stephen E. Calvert } \\
\text { Tommy D. Dickey } \\
\text { Robert F. Anderson } \\
\text { Rick Spinrad } \\
\text { EXECUTIVE DIRECTOR } \\
\text { Judi Rhodes }
\end{gathered}
$$

CORPORATE/INSTITUTIONAL SPONSORS

Aanderaa Instruments, Inc. Woburn, MA, USA

Chishitsu Chosa-Jo, Ibaraki, Japan

GE Astro Space Division Princeton, NJ, USA

John G. Shedd Aquarium, Chicago, IL, USA

Monterey Bay Aquarium Research Institute, Pacific Grove, CA, USA

National Marine Fisheries Service, Silver Spring, MD, USA

Ober, Kaler, Grimes \& Shriver. Washington, DC, USA

RD Instruments, San Diego, CA, USA

Scripps Institution of Oceanography, La Jolla, CA, USA

Woods Hole Oceanographic Institution, Woods Hole, MA, USA

\section{OCEANOGRAPHY}

CO-EDITORS

Larry P. Atkinson

Center for Coastal Physical Oceanography

Old Dominion University

Crittenton Hall

Norfolk, VA 23529

(804) 683-5558

Internet: atkinson@ccpo.odu.edu

Connie Sancetta

National Science Foundation

Ocean Sciences Division Room 725

4201 Wilson Blvd.

Arlington, VA 22230

(703) 306-1586

Internet: csancett@ nsf.gov

ASSOCIATE EDITORS

James W. Ammerman

Department of Oceanography

Texas A\&M University

College Station, TX 77843 USA

(409) $845-5105$

Gregg J. Brunskill

Australian Institute of Marine Science

PMB No. 3, Townsville, M.C.

Queensland 4810, Australia

(077) 789 211; FAX (077) 725852 ;

Internet: g_brunskill@aims.gov.au 